\title{
ANALISIS KINERJA PERDAGANGAN KONTRAK BERJANGKA LOGAM MULIA PADA PERIODE OKTOBER 2009 - DESEMBER 2009
}

\author{
Mohamad Heykal ${ }^{1}$; Erlin ${ }^{2}$ \\ Jurusan Akuntansi, Fakultas Ekonomi dan Bisnis, Bina Nusantara University \\ Jln. K.H. Syahdan No. 9, Kemanggisan, Palmerah, Jakarta Barat 11480
}

\begin{abstract}
As a competitive in the industry had been caused the price of Gold commodity become fluktuative dan it make the commodity supply had not been guarantee. Based on that the investor had been tried to make commodity trading that can be used as a hedging that become effective to ensure the strategy from company management from the effect of price fluctuation that can be happen every time. The contract periode that had done in this research from the periode October, November, and December, where the fluctuation of spot and futures price can be calculated based on the correlation between spot and future price. Correlation had been used to put the hedge ratio and also the optimum contract. VaR Methode had been used to show the total risk.The average of VaR spot is $R p$ 12.205.950.And the VaR futures is $R p$ 3716803. Based On the condition of high risk and also high return, but it also depend on the investor.
\end{abstract}

Keywords: gold future contract, hedging, futures, VaR

\begin{abstract}
ABSTRAK
Semakin tinggi tingkat persaingan industri mengakibatkan harga dari komoditas Gold menjadi fluktuatif, dan kepastian ketersediaan komoditas tersebut semakin tidak terjamin. Sehingga para investor berusaha untuk melakukan perdagangan berjangka yang dapat dimanfaatkan sebagai sarana lindung nilai (hedging) yang sangat efektif untuk menunjang kemantapan strategi manajemen perusahaan dari pengaruh fluktuasi harga yang dapat terjadi setiap waktu. Periode kontrak yang dilakukan dalam penelitian yaitu periode oktober, November dan Desember, di mana fluktuasi perubahan harga spot dan futures nya dihitung untuk mengukur korelasi hubungan antara harga futures dan spot. Korelasi digunakan untuk menentukan hedge ratio dan nilai optimum kontrak. Metode VaR digunakan untuk menunjukan total risiko.VaR spot untuk kontrak bulan Oktober, November dan desember memiliki hasil yang lebih besar dari VaR futures. Rata-rata VaR spot Rp. 12.205.950 sedangkan untuk VaR futures Rp.3.716.803 VaR spot menunjukan hasil perbandingan yang lebih besar dari VaR futures maka mengindikasikan risiko kerugian dari bulan oktober hingga Desember semakin kecil. Kontrak berjangka emas yang diambil sebaiknya memiliki VaR yang lebih besar. Karena semakin besar risiko yang diperoleh semakin besar juga profit yang didapat. Akan tetapi semua tergantung pada karakter produsen, trader dan investor.
\end{abstract}

Kata kunci: kontrak berjangka emas, lindung nilai, futures, VaR 


\section{PENDAHULUAN}

\section{Latar Belakang Penelitian}

Pada masa krisis seperti sekarang ini banyak masalah yang timbul dan mengganggu perekonomian. Berbagai hal dilakukan untuk dapat tetap bertahan di dunia bisnis. Salah satu cara yang dapat dilakukan untuk bertahan adalah dengan berinvestasi. Investasi dalam arti luas dapat dikatakan sebagai pengorbanan dollar sekarang untuk dollar dimasa depan. Ada berbagai macam cara berinvestasi, bisa dimulai dari cara menabung seperti deposito atau berupa penanaman modal disuatu bisnis tertentu. Investasi merupakan suatu komitmen penempatan dana pada satu atau beberapa objek investasi dengan harapan akan mendapatkan keuntungan di masa mendatang. Keuntungan merupakan salah satu sisi baik dari investasi, namun dibalik kebaikan tersebut terdapat risiko.

Salah satu sarana investasi yang akan dibahas saat ini adalah sarana investasi yang dapat mengurangi risiko. Mengurangi risiko dapat dilakukan dengan berbagai macam cara. Salah satunya dengan melakukan diversifikasi investasi ataupun dengan melakukan hedging. Pada kesempatan ini yang akan dibahas adalah investasi untuk mengurangi resiko dengan cara melakukan hedging pada perdagangan kontrak berjangka. Perdagangan berjangka memiliki banyak jenis underlying asset, seperti komoditas, indeks. Perdagangan berjangka dengan underlying asset komoditas mulai banyak di perdagangkan, Hal ini karena semakin tinggi tingkat persaingan industri yang mengakibatkan harga dari komoditas tersebut menjadi fluktuatif, dan kepastian ketersediaan komoditas tersebut semakin tidak terjamin. Komoditas yang sedang banyak diminati adalah komoditas dari sektor logam mulia. Sehingga saat ini kontrak berjangka yang akan dibahas adalah kontrak berjangka pada logam mulia (Gold). Hal ini dimungkinkan karena semakin meningkatnya inflasi, kredit macet, jatuhnya bursa saham dan munculnya kebijakan-kebijakan fiskal dan moneter turut memicu peminat logam mulia. Selain itu logam mulia tidak terpengaruh oleh inflasi (zero inflation) dan memiliki nilai standar international.

Hal ini menyebabkan timbulnya keyakinan dari investor bahwa harga dari logam mulia ini akan meningkat. Sehingga para investor berusaha untuk melakukan perdagangan berjangka, karena perdagangan berjangka dapat dimanfaatkan sebagai sarana lindung nilai (hedging) yang sangat efektif untuk menunjang kemantapan strategi manajemen perusahaan dari pengaruh fluktuasi harga yang dapat terjadi setiap waktu.Dari penelitian ini diharapkan dapat memberikan gambaran mengenai mekanisme lindung nilai yang akan dilakukan dengan kontrak berjangka emas di bursa berjangka Jakarta yang membawa manfaat dalam mengantisipasi risiko fluktuasi harga emas. Lindung nilai bukan kegiatan yang bersifat spekulasi, karena untuk melakukannya dibutuhkan pengetahuan yang memadai dan perhitungan yang cermat. Diharapkan dari hasil penelitian ini dapat dijadikan referensi dan informasi mengenai hal-hal yang harus diperhatikan oleh pihak yang ingin melakukan lindung nilai melalui kontrak berjangka tersebut.

Adapun dalam penelitian ini, penulis membatasi ruang lingkup pada: (1) kontrak berjangka yang akan dianalisa adalah kontrak berjangka emas yang diperdagangkan di Bursa Berjangka Jakarta; (2) periode penelitian dilakukan pada kontrak berjangka bulan Oktober, November dan bulan Desember tahun 2009; (3) transaksi hedging yang dilakukan setiap bulannya dimana tanggal pelaksanaan pada tahun 2009 pada bulan Oktober hingga Desember.

\section{Tujuan dan Manfaat Penelitian}

Tujuan penelitian yaitu untuk (1) menentukan resiko yang timbul karena adanya perbedaan harga spot dengan futures (basis risk); (2) menentukan hedge ratio dari hedging kontrak logam mulia; (3) menghitung tingkat kerugian maksimum dari kontrak berjangka dengan metode Value at Risk. 
Sementara itu, manfaat penelitian yaitu sebagai (1) rekomendasi bagi pihak yang ingin melindungi asset nya dari perubahan harga emas yang fluktuatif; (2) bahan informasi dan pertimbangan bagi pihak yang ingin menggunakan kontrak berjangka sebagai sarana lindung nilai dalam menentukan langkah-langkah kebijaksanaan dan penentuan akan perlu tidaknya menggunakan strategi lindung nilai (hedging) di masa yang akan datang; (3) mengetahui proses transaksi perdagangan kontrak berjangka komoditas emas di pasar berjangka; (4) mengetahui besar resiko yang mungkin akan terjadi dengan menggunakan metode $\mathrm{VaR}$

\section{METODE PENELITIAN}

Dalam penelitian ini penulis melakukan penelitian dengan data-data kepustakaan, yaitu penelitian yang dilakukan untuk memperoleh informasi teoritis yang berhubungan dengan topik, kegiatan pengumpulan data dilakukan dengan menggunakan berbagai literatur, buku dan sumber lainnya yang berhubungan dengan masalah yang akan di teliti dengan cara membaca, mengumpulkan, dan mencatat serta menganalisisnya. Termasuk landasan teoritis yang menjadi dasar dari penelitian ini.

\section{Investasi dan Tingkat Pengembalian}

Menurut Sunariyah (2004), kegiatan investasi adalah penanaman modal untuk satu atau aktiva yang dimiliki dan biasanya berjangka waktu lama dengan harapan mendapatkan keuntungan dimasamasa yang akan datang. Sedangkan menurut Bodie, Kane, \& Marcus (2009), investasi adalah komitmen atas sejumlah dana atau sumber daya lainya yang dilakukan pada saat ini, dengan tujuan memperoleh keuntungan dimasa yang akan datang. Dari pengertian tersebut dapat disimpulkan bahwa investasi merupakan suatu komitmen penempatan dana pada satu atau beberapa objek investasi dengan harapan akan mendapatkan keuntungan dimasa mendatang. Kesimpulan tersebut dapat dijelaskan bahwa motif utama investasi adalah mencari keuntungan atau laba dalam jumlah tertentu. Keuntungan merupakan salah satu sisi yang baik dari investasi, namun dibalik kebaikan tersebut terdapat risiko. Investor harus dapat bertanggung jawab atas kedua hal tersebut yaitu prospek tingkat pengembalian dari investasi serta risiko yang ada.Sementara Definisi tingkat pengembalian (return) menurut Ardiyos (2001) adalah hasil yang diperoleh dari penanaman modal tertentu didalam suatu perusahaan didalam periode tertentu.

Sedangkan menurut Sundjaja \& Barlian (2002) yang dimaksud dengan tingkat pengembalian adalah total keuntungan atau kerugian yang dialami pemilik modal atau investor dalam suatu periode tertentu yang dihitung dengan membagi perubahan nilai aktiva ditambah pembagian hasil dalam periode tersebut dengan nilai investasi awal periode. Menurut Sunaryo (2007), return adalah tingkat hasil pengembalian yang diharapkan.Dari pengertian diatas jelas bahwa yang dimaksud dengan return dari suatu investasi adalah tingkat hasil pengembalian yang diperoleh dari suatu dana atau modal yang ditanamkan pada suatu investasi. Pada investasi kontrak berjangka tingkat pengembalian yang diperoleh investor dihitung berdasarkan posisi kontrak yang dipegangnya, yaitu berdasarkan selisih harga ketika investor memasuki pasar dan saat keluar pasar, hal ini akan menentukan apakah investor akan memperoleh keuntungan atau kerugian dari dana yang telah diinvestasikan.

\section{Perdagangan Kontrak Berjangka}

Perdagangan Berjangka atau juga dikenal dengan sebutan futures contract menurut Hull (2005) adalah suatu perjanjian atau kesepakatan untuk membeli atau menjual aktiva tertentu pada saat tertentu dan dengan harga tertentu pada kurun waktu tertentu dimasa yang akan datang. Bursa 
berjangka adalah tempat atau fasilitas yang memperjual belikan kontrak atas sejumlah komoditi atau instrumen keuangan dengan harga tertentu yang penyerahan barangnya disepakati akan dilakukan pada saat yang akan datang. Dalam ilmu linguistik, kata komoditi ini mulai dikenal dan dipergunakan di Inggris pada abad ke 15 yang berasal dari bahasa Perancis yaitu commodité yang berarti sesuatu yang menyenangkan dalam kualitas dan layanan; dalam bahasa Latin disebut commoditas yang mengartikan pada berbagai cara untuk pengukuran yang tepat dari sesuatu; keadaan waktu ataupun kondisi yang pas, kualitas yang baik; kemampuan untuk menghasilkan sesuatu atau aktiva; dan nilai. Di Indonesia dapat diartikan sebagai: barang dagangan, benda niaga, atau bahan mentah yang dapat digolongkan menurut mutunya sesuai dengan standar perdagangan internasional, misalnya gandum, oil, emas, karet, kopi dan sebagainya.

Perdagangan kontrak berjangka dapat dilakukan dalam bursa yang dikenal dengan nama bursa berjangka. Bursa berjangka berbeda dengan bursa saham. Dalam bursa berjangka, Kontrak perdagangan berjangka tidak diterbitkan sebagaimana dalam penerbitan saham tetapi "terbentuk" sewaktu ada pihak pembeli (long) dan ada pihak pembeli (short) Pihak pembeli dan penjual kontrak menciptakan kontrak baru setiap kali mereka mencapai kesepakatan. Sementara dalam bursa saham, jumlah efek yang terdaftar adalah terbatas penjual. Kecuali emiten tidak dapat menciptakan saham itu karena di pasar modal penjual harus memiliki atau meminjam efek, sebelum boleh menjualnya. Penjual tidak boleh short. Investor di pasar modal hanya akan mungkin merealisasi rugi atau laba pada waktu menjual saham yang dimilikinya. Pasar modal yang terjadi adalah perdagangan fisik dimana jual beli saham dilakukan secara fisik sehingga terjadi serah terima saham secara fisik dengan kewajiban membayar senilai $100 \%$ dari transaksi.Perdagangan berjangka, sebagai penjual atau pembeli dalam pasar berjangka wajib menyerahkan sejumlah dana hanya sekitar $5-10 \%$ dari nilai komoditi yang ditransaksikan sebagai itikad baik (good faith) yang disebut margin. Mekanisme perdagangan berjangka dapat dilihat seperti di bawah ini.

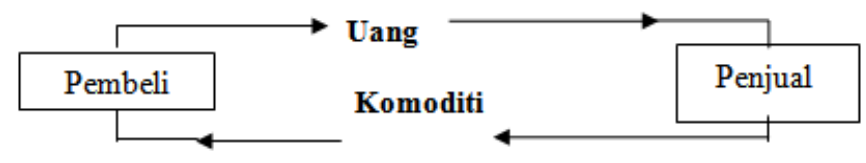

Gambar 1 Mekanisme Perdagangan Berjangka

Kewajiban kedua pihak dengan adanya clearinghouse

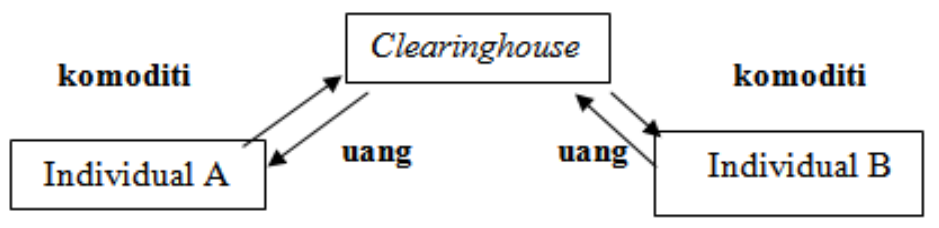

Gambar Fungsi Clearinghouse di Pasar Berjangka 


\section{Siklus Perdagangan Berjangka}

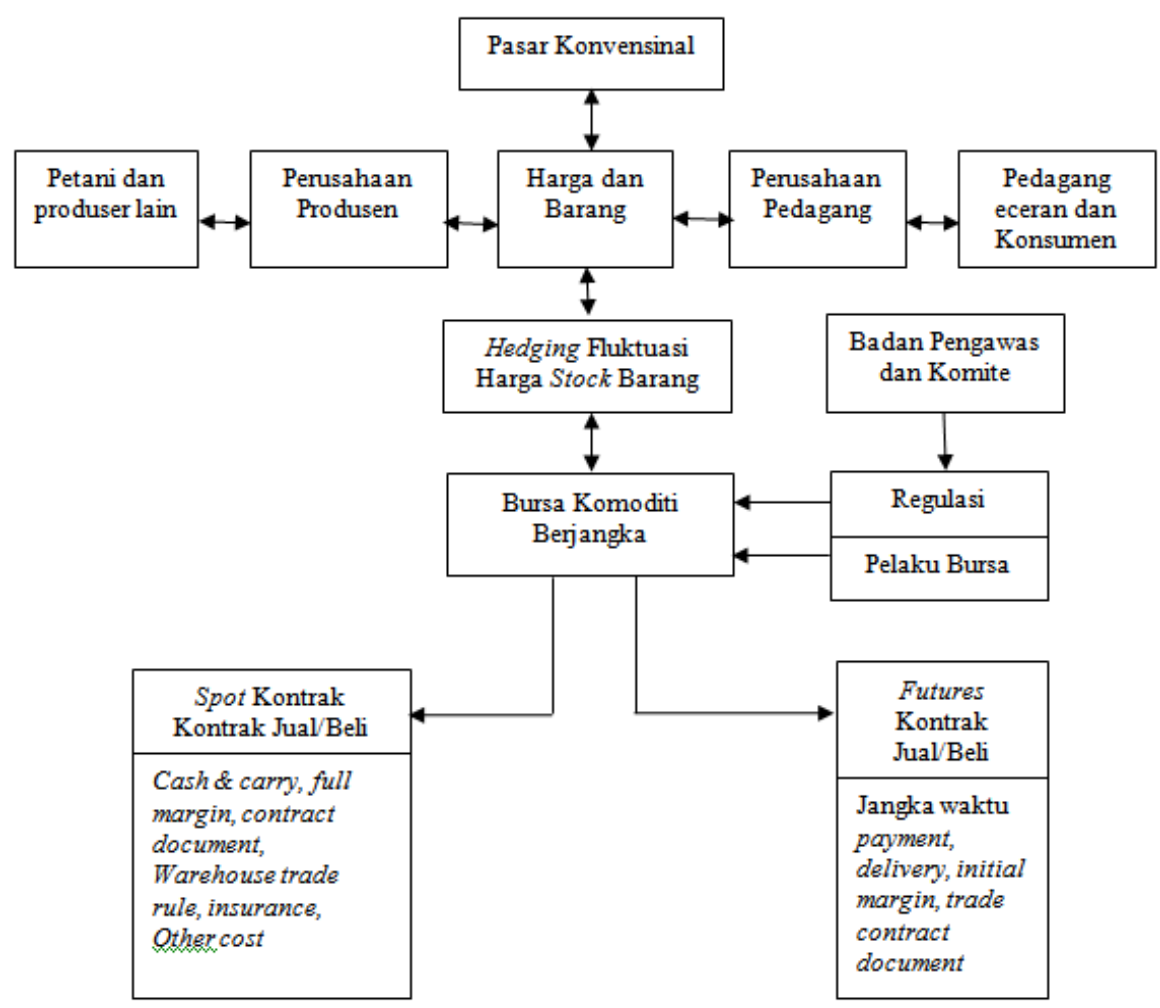

Gambar 3 Siklus Perdagangan Berjangka

\section{Pengertian Derivatif}

Derivatif terdiri dari efek yang diturunkan dari instrumen efek lain yang disebut underlying. Definisi derivatif menurut Siahaan (2008) adalah kontrak antara dua pihak pembeli dan penjual yang di dalam kontraknya terdapat berbagai hal yang telah disepakati bersama sekarang, tetapi realisasinya atau pelaksanaan hal tersebut adalah nanti pada tanggal tertentu dimasa yang akan datang (dalam kurun waktu tertentu di masa yang akan datang). Sementara Siahaan \& Manurung (2006) mendefinisikan derivatif adalah semacam kendaraan keuangan (peranti keuangan) yang diturunkan dari induknya. Induknya dapat berupa aktiva keuangan saham atau obligasi, komoditi, atau berbagai indeks seperti IHSG, LQ45, S\&P500, Nikkei, Hanseng dan sebagainya. Derivatif juga dapat dikelompokan atas forward contracts, options contracts, swaps contracts. Menurut Bursa Berjangka Jakarta kontrak derivatif adalah suatu kontrak yang memiliki tingkat gejolak harga yang amat tinggi, terkadang lebih bergejolak daripada asset acuan (underlying asset) dan ini dapat menjadikan salah satu pihak menderita kerugian yang sangat besar sehingga tidak mampu menyelesaikan transaksi. Instrumen investasi derivative terdiri dari forward, option, dan swap contracts.

\section{Forward Contracts}

Kontrak penyerahan kemudian (forward contracts) sama dengan kontrak berjangka (futures), yaitu merupakan kesepakatan antara dua pihak untuk membeli dan menjual aktiva yang dilakukan pada tanggal tertentu dimasa yang akan datang dan pada harga tertentu yang telah disepakati pada saat kontrak ditandatangani. Forward contracts diperdagangkan di luar bursa atau over the counter market. 


\section{Option Contracts}

Kontak opsi pada dasarnya dibedakan menjadi dua macam, yaitu call sebagai hak beli dan put sebagai hak jual. Pemilik call atau pembeli call memiliki hak untuk membeli aktiva tertentu pada harga tertentu dan pada tanggal tertentu di masa yang akan datang. Sebaliknya pembeli put atau pemilik put adalah hak untuk menjual aktiva tertentu pada harga tertentu dan pada tanggal tertentu di masa yang akan datang.

\section{Swaps Contracts}

Swaps adalah kesepakatan antara dua pihak (perusahaan) untuk saling mempertukarkan arus kas dimasa tertentu (selama kurun waktu tertentu) yang akan datang. Dalam kesepakatan ditentukan secara spesifik tanggal pembayaran tunai dan cara menghitung jumlah tunai yang akan saling dipertukarkan. Pasar derivatif memiliki beberapa fungsi dan kegunaan, diantaranya adalah sebagai risk transfer, price discovery, dan transaction integrity.

\section{Sebagai Risk Transfer}

Fungsi ekonomis yang terpenting adalah sebagai alat pemindahan risiko (transfer of market risk) yakni pemindahan risiko terhadap perubahan harga secara drastis atau perubahan harga portofolio aktiva yang tidak sesuai oleh pihak yang ingin menghindarinya (hedgers) kepada pihak yang bersedia atau mampu mengendalikanya dengan lebih baik (speculators).

\section{Price Discovery}

Proses terjadinya harga suatu aktiva di mana harga seseorang bersedia membelinya dan orang lain bersedia menjual aktiva pada harga tersebut atau harga kesepakatan antara penawaran dan permintaan suatu komoditi (aktiva).

\section{Transaction integrity}

Maksudnya adalah dalam perekonomian yang hukumnya dan prasarana komersialnya belum maju dan berkembang bursa komoditi berjangka dapat memainkan peranan penting sebagai penengah untuk menghubungkan kredit, sehingga merangsang bursa di dalam pembentukan harga berdasarkan pasar.

\section{Sarana Asuransi dan Perlindungan Nilai}

Derivatif merupakan alat untuk mengalihkan risiko. Lindung nilai merupakan suatu strategi yang diciptakan untuk mengurangi timbulnya risiko bisnis yang tidak terduga.

\section{Spekulasi dan Arbitrasi}

Arbitrasi atau juga dikenal dengan istilah asing arbitrage ini bisa diartikan sebagai suatu tindakan mengambil keuntungan dengan memanfaatkan perbedaan antara satu aktiva dan aktiva lainnya.

\section{Lindung Nilai}

Lindung nilai atau dalam bahasa Inggris disebut hedge dalam dunia keuangan dapat diartikan sebagai suatu investasi yang dilakukan khususnya untuk mengurangi atau menghilangkan risiko pada suatu investasi lain. Lindung nilai adalah merupakan suatu strategi yang diciptakan untuk mengurangi timbulnya risiko bisnis yang tidak terduga. 
Seorang hedger atau pelaku lindung nilai biasanya akan melakukan investasi pada suatu sekuritas yang diyakini memiliki harga dibawah nilai pasar yang seharusnya dan menggabungkannya dengan sekuritas lainnya yang berhubungan dengan sekuritas tersebut. Holbrook Working, seorang perintis teori lindung nilai menyebut teori ini dengan istilah speculation in the basis (spekulasi dasar) di mana dasarnya adalah perbedaan antara nilai teoritis lindung nilai dengan nilai pasar sesungguhnya.

Dalam jurnalnya yang berjudul Hedging and value at risk: a semi-parametric approach. Cao, Haris \& Shen (2010) berpendapat bahwa the non-normality of financial asset returns has important implications for hedging. In particular, in contrast with the unambiguous effect that minimumvariance hedging has on the standard deviation, it can actually increase the negative skewness and kurtosis of hedge portfolio returns. Thus, the reduction in Value at Risk (VaR) and Conditional Value at Risk (CVaR) that minimum-variance hedging generates can be significantly lower than the reduction in standard deviation.

Kegiatan hedging atau aksi lindung nilai dapat dikelompokan dalam 2 kelompok besar, yaitu selling hedge dan buying hedge. Selling hedge atau disebut juga short hedge, adalah suatu tindakan yang dilakukan para hedger dengan mengambil posisi jual di pasar berjangka dalam rangka melindungi nilai persediaan bahan baku mereka dari fluktuasi harga. Buying hedge atau di sebut juga long hedge, adalah suatu tindakan yang dilakukan para hedger dengan mengambil posisi beli di pasar berjangka dalam rangka melindungi usaha mereka dari fluktuasi harga komoditi yang mereka beli di pasar fisik.

\section{Manfaat Hedging}

Hedging memberikan manfaat bagi hedger, yaitu: (1) hedging merupakan sarana mengurangi atau menghilangkan resiko kerugian yang terjadi dari fluktuasi harga; (2) hedging memberikan kepastian berusaha, serta pengendalian persedian bahan baku dan komoditi pertanian; (3) hedging memberikan penyediaan dana yang lebih besar serta lebih aman (pada umumnya komoditi yang tidak di-hedging akan mendapat pinjaman dana atau kredit dari bank sebesar $50 \%$ dari nilai komoditi tersebut, sedangkan untuk komoditi yang telah di-hedge akan mendapat pinjaman dana sebesar $90 \%$ dari nilai komoditi yang bersangkutan); (4) kegiatan hedging atau lindung nilai banyak digunakan oleh para eksportir sebagai langkah perlindungan dari mata uang yang digunakan importir sebagai pembayaran, yang dikenal sebagai lindung nilai terhadap risiko gejolak nilai tukar mata uang; (5) kenaikan suku bunga pinjaman, yang berisiko bagi peminjam dan bagi pemberi pinjaman apabila suku bunga turun; (6) ekuitas, risikonya adalah jatuhnya nilai ekuitas yang dimilikinya.

Beberapa bentuk kegiatan yang dapat dikategorikan sebagai aksi lindung nilai adalah: (1) kontrak serah dan kontrak berjangka adalah merupakan suatu lindung nilai terhadap risiko pergerakan harga di pasar; (2) lindung nilai terhadap risiko kredit macet; dimana risiko kredit adalah merupakan suatu risiko dalam bisnis perbankan namun merupakan risiko yang tidak dikehendaki oleh para pedagang, maka untuk melakukan lindung nilai pedagang menjual obligasi yang dipegangnya dengan potongan harga; (3) lindung nilai terhadap mata uang digunakan oleh para investor guna melindungi investasinya di negara lain juga oleh dunia industri yang menggunakan berbagai mata uang dalam perdagangannya.

\section{Hedge Ratio}

Menurut Hull (2005), hedge ratio merupakan rasio dari nilai kontrak yang dapat diambil dalam future contract. Hedge ratio merupakan koefisiensi korelasi antara perubahan harga spot $\Delta \mathrm{S}$ dan harga futures $\Delta \mathrm{F}$ dengan standar deviasi $\Delta \mathrm{S}$ dan $\Delta \mathrm{F}$. Rumus menghitung hedge ratio:

$$
h *=\rho \frac{\sigma \Delta s}{\sigma S F}
$$


Di mana:

$\sigma \mathrm{S}=$ deviasi standar $\Delta \mathrm{S}$ (perubahan harga pasar)

$\sigma \mathrm{F}=$ deviasi standar $\Delta \mathrm{F}$ (perubahan harga kontrak berjangka)

$\rho=$ koefisien korelasi antara $\Delta \mathrm{S}$ dan $\Delta \mathrm{F}$.

$\mathrm{h}^{*}=$ hedge ratio

\section{Value at Risk (VaR)}

Menurut Hull (2005), VaR menunjukan sebuah angka tunggal yang menjumlahkan seluruh resiko yang ada dalam portofolio. Perhitungan VaR akan membuat suatu kesimpulan yang mudah untuk dimengerti, dengan pola hasil sebagai berikut yakin x persen bahwa kita tidak akan rugi lebih dari v dollar dalam jangka waktu $n$ hari. Rumus menghitung VaR:

$$
\text { VAR }=\mathbf{N} \times \text { s } x \sqrt{t} \times \text { Zpoint }
$$

Keterangan:

$\mathrm{N}$ : Jumlah asset atau portofolio

$\mathrm{S}$ : standar deviasi dari suatu asset atau portofolio

$\mathrm{t}$ : waktu

zpoint : tingkat keyakinan (confidence level), dicari dengan fungsi excel NORMSINV (confidence level)

\section{HASIL DAN PEMBAHASAN}

Penelitian yang dilakukan dalam hal ini adalah mengenai Gold Futures Contract pada tahun 2009 pada bursa berjangka Jakarta. Data yang di gunakan adalah data historical price pada settlement price dari harga spot dan futures gold yang berasal dari BBJ (Bursa Berjangka Jakarta). Kontrak berjangka yang di teliti adalah kontrak daily pada bulan Oktober, November dan Desember. Analisis dan simulasi pada masing - masing kontrak diawali dengan menghitung fluktuasi perubahan harga spot dan fluktuasi perubahan harga futures untuk mengetahui besarnya ratio asset yang harus di hedging dengan menggunakan rasio atau (hedge ratio), serta nilai kontrak berjangka optimum yang diambil $\left(\mathrm{N}^{*}\right)$ pada masing-masing kontrak. Perhitungan VaR dilakukan untuk menentukan tingkat kerugian maksimum yang akan dialami Gold futures contract. Analisis kontrak berjangka gold untuk setiap periode kontrak berjangka dilakukan berulang dengan cara yang sama hingga periode Desember.

Setelah melakukan analisis kontrak berjangka gold di bursa berjangka Jakarta selama 3 periode, dapat dilihat bahwa tiap bulan kontrak menghasilkan hedging yang berbeda-beda. Lebih lengkapnya dapat dilihat pada tabel yang disajikan berikut ini.

Tabel 1 Perbandingan Kinerja dan Langkah Hedging Gold Futures Contract

\begin{tabular}{|c|c|c|c|}
\hline & Oktober & November & Desember \\
\hline Fluktuasi Perubahan harga Spot & 7.370 & 7.672 & 5.403 \\
\hline Fluktuasi Perubahan harga Futures & Rp. 1.853 & Rp. 1.907 & Rp. 2.977 \\
\hline Korelasi & 0,338 & 0,79 & 0,549 \\
\hline Hedge Ratio ( $\left.h^{*}\right)$ & $134.46 \%$ & $318 \%$ & $99 \%$ \\
\hline Nilai Kontrak Optimum (N*) & 13 & 32 & 10 \\
\hline Fluktuasi Harga Spot & 0,023 & 0,023 & 0,015 \\
\hline VaR Pasar Spot & 13.563 .761 & 14.354 .576 & 8.699 .515 \\
\hline Fluktuasi harga Futures & 0,0059 & 0,00586 & 0,0086 \\
\hline VaR Pasar Futures & 3.082 .992 & 3.352 .546 & 4.714 .871 \\
\hline Selisih VaR per satu Unit Kontrak & 10.480 .769 & 11.002 .030 & 3.984 .644 \\
\hline
\end{tabular}


Fluktuasi harga spot terbesar yaitu terjadi pada bulan November yaitu sebesar Rp.7.672 per hari. Sedangkan fluktuasi perubahan harga spot terkecil yaitu pada bulan desember sekitar Rp. 5.403 per hari nya. Selama tiga bulan kontrak rata- rata fluktuasi spot nya adalah Rp. 6.815 per hari. Ratarata fluktuasi harga futures yaitu Rp. 2.245 per hari. Fluktuasi harga futures tertinggi pada bulan Desember sebesar 2.977 per harinya. Sedangkan fluktuasi terendah terjadi pada bulan Oktober sebesar Rp.1.853 per hari.Pada bulan oktober, November dan desember fluktuasi harga spot jauh lebih besar dari fluktuasi harga futures. Berdasarkan perbandingan rata-rata perubahan harga spot dan futures, harga spot bergerak Rp.4.570 lebih fluktuatif dibandingkan harga futures gold.

Berdasarkan korelasinya bulan November memiliki korelasi teringgi $>0.7$ yang artinya memiliki korelasi yang kuat dan berbanding lurus. Sedangkan untuk bulan oktober dan desember korelasi nya berada $>0.3$ yang artinya perbandingan harga spot dan future bersifat medium tidak terlalu kuat dan tidak terlalu lemah. Hedge Ratio tertinggi pada bulan November sebesar $318 \%$ dengan nilai kontrak paling banyak disarankan untuk hedging yaitu 32 kontrak. Sama seperti pada bulan desember nilai kontrak yang disarankan untuk di hedging sebanyak 10 kontrak karena semakin banyak akan kontrak yang di hedging akan semakin besar profitabilitas yang akan di hasilkan. Sedangkan hedge ratio dengan jumlah terendah pada bulan Desember sebesar 10,6\% dengan nilai kontrak yang disarankan untuk di hedging sebanyak 10 kontrak. Hedge ratio dengan persentase diatas 95\% memberikan nilai kontrak optimum sebanyak 10 kontrak serta memberikan hedging benefit kepada hedger.

VaR pasar spot dengan tingkat keyakinan 95\% resiko yang terjadi pada bulan oktober, November dan desember memiliki rata-rata Rp. 12.205.950. Risiko terendah dari pasar spot yaitu pada bulan Desember sebesar Rp. 8.699.515, risiko tertinggi pada bulan November Rp. 14.354.576. VaR futures memiliki rata-rata Rp. 3.716.803. Pada umumnya risiko yang dialami pasar spot lebih besar dari pada harga futures. Jika VaR spot menunjukan hasil perbandingan yang lebih besar dari VaR futures maka mengindikasikan risiko kerugian yang semakin kecil. Sementara jika VaR spot menunjukan hasil perbandingan yang lebih kecil dari VaR futures maka mengindikasikan risiko kerugian yang semakin besar juga. Perbandingan kinerja VaR spot terhadap VaR futures adalah: (1) kontrak bulan Oktober, 1: 4,4; (2) kontrak bulan November, 1: 4,3; (3) kontrak bulan desember, 1:1,9. Dari data yang telah dihitung dapat dilihat bahwa kontrak berjangka pada gold di bursa BBJ (dengan asumsi kebutuhan sebesar 10.000 gram) dapat memberikan manfaat hedging yang memiliki ciri-ciri yaitu: (1) fluktuasi perubahan harga spot lebih besar dibanding harga futures; (2) hedge ratio pada umumnya lebih besar dari 95\% dengan nilai kontrak optimum minimal 10 kontrak; (3) rasio perbandingan antara VaR spot dan VaR futures adalah $1: \leq 2$.

\section{PENUTUP}

Berdasarkan penelitian yang sudah dilakukan, maka penulis selaku peneliti mencoba untuk menarik kesimpulan bahwa: (1) fluktuasi perubahan harga spot dari bulan oktober hingga desember memiliki nilai yang lebih besar dari harga futures yang berarti harga spot jauh lebih fluktuatif dari harga pasar berjangka; (2) nilai optimum kontrak berjangka terbanyak terjadi pada bulan November sebanyak 32 kontrak dengan hedge ratio di atas 300\%. Sedangkan paling sedikit 10 kontrak yang terjadi pada bulan Oktober dengan hedge ratio 99\%. Kontrak bulan Oktober dan November membawa profit yang lebih besar dari kontrak bulan Desember, karena semakin besar kontrak yang di hedging akan semakin besar juga profit yang akan di hasilkan; (3) VaR spot untuk kontrak bulan oktober, November dan desember memiliki hasil yang lebih besar dari VaR futures. Rata-rata VaR spot Rp. 12.205.950 sedangkan untuk VaR gold Rp. 3.716.803. VaR spot menunjukan hasil perbandingan yang lebih besar dari VaR futures maka mengindikasikan risiko kerugian dari bulan Oktober hingga Desember semakin kecil. 
Selain itu penulis selaku peneliti juga berpandangan bahwa aksi lindung nilai dengan memanfaatkan kontak berjangka dapat mengurangi risiko fluktuasi dari pergerakan harga dan tedapat beberapa hal yang harus dipertimbangkan apabila ingin melakukan lindung nilai kontrak berjangka gold, antara lain: (1) hedging sebaiknya dilakukan apabila hedge ratio diatas $95 \%$ dengan nilai kontrak optimum 10 kontrak. Semakin besar hedge ratio maka semakin banyak kontrak yang digunakan dan semakin berisiko harga spot dan futures maka semakin besar pula hedge ratio. Kondisi ini hanya memungkinkan jika fluktuasi perubahan harga spot lebih besar dari harga futures, artinya jika pasar spot yang lebih fluktuatif dari pasar berjangka, produsen sebaiknya mengamankan assetnya dengan kontrak berjangka; (2) sebaiknya kontrak berjangka yang diambil memiliki fluktuasi perubahan harga futures dibawah Rp. 2.977 dan fluktuasi harga futures dibawah 0,0086; (3) VaR dalam arti positif menunjukan nilai laba maksimum dengan asumsi tertentu. Sedangkan VaR dengan arti negative menunjukan nilai kerugian maksimum dengan asumsi tertentu. Untuk mendapatkan laba yang lebih besar maka yang menjadi pertimbangan adalah VaR yang nilai ny lebih besar. Karena semakin besar risiko yang diperoleh maka semakin besar juga profit yang didapat. Maka dalam hal ini direkomendasikan memakai kontrak berjangka dengan risiko nilai kerugian yang lebih tinggi. Akan tetapi semua tergantung pada karakter produsen, trader ataupun calon investor.

\section{DAFTAR PUSTAKA}

Ardiyos, 2001. Kamus Ekonomi, edisi pertama. Jakarta : Citra Harta Prima

Bodie, Z., Kane, A., \& Marcus, A.J. (2009). Investments. Eighth Edition. New York: McGraw-HillIrwin

Cao, Z., Harris, R., \& Shen, J. (2010). Hedging and value at risk: A semi-parametric approach. The Journal of Futures Markets, retrieved on June 19, 2010 from http://proquest.umi.com/pqdweb?did=2949721271\&sid=1\&Fmt=2\&clientd=68814\&RQT =30 $\underline{9 \& \mathrm{VName}=\mathrm{PQD}}$

Hull, J. H. (2005). Fundamental of future and option (5th ed.). USA: Pearson Education.

Siahaan, H. P., \& Manurung, A. H. (2006). Aktiva derivative. Jakarta: Elex Media Komputindo.

Siahaan, H. (2008). Seluk beluk perdagangan instrument derivatif. Jakarta: Elex Media Komputindo.

Sunariyah, (2004). Pengantar Pengetahuan Pasar Modal, edisi keempat. Yogyakarta : Penerbit UPPAMP YKPN.

Sundjaja, R.S., \& Barlian, I. (2002). Manajemen Keuangan, Jakarta: PT Prenhallindo.

Sunaryo, J. (2007). Manajemen risiko finansial. Jakarta: Salemba Empat. 


\section{RIWAYAT PENULIS}

Mohamad Heykal lahir di Jakarta pada 26 November. Menamatkan pendidikan sarjana stara 1 di Universitas Trisakti Jurusan akuntansi dan strata 2 di Universitas Indonesia program pasca sarjana kekhususan ekonomi dan keuangan syariah. Pengalaman mengajar di Universitas Trisakti, Universitas YARSI dan Universitas Muhammadiyah Jakarta. Mengajar di Universitas Bina Nusantara sejak 2008 dan bergabung di jurusan akuntansi sejak 1 April 2010.

Erlin lahir di Karawang pada 27 Februari. Menamatkan pendidikan strata 1 di jurusan akuntansi Universitas Bina Nusantara. Menguasai bahasa Inggris dan Mandarin. Kini bekerja di Jakarta. 